\title{
Biochar Mitigates Combined Effects of Drought and Salinity Stress in Quinoa
}

\author{
Aizheng Yang ${ }^{1}$, Saqib Saleem Akhtar ${ }^{2,3}$, Lin Li ${ }^{4, *}$, Qiang Fu ${ }^{1, *}$, Quanfeng $\mathrm{Li}^{5}$, \\ Muhammad Asif Naeem ${ }^{6}$, Xinyao He ${ }^{1}$, Ze Zhang ${ }^{1}$ and Sven-Erik Jacobsen ${ }^{7}$ (D) \\ 1 School of Water Conservancy and Civil Engineering, Northeast Agriculture University, Harbin 150030, \\ China; aizheng.yang@neau.edu.cn (A.Y.); xinyao.he@hotmail.com (X.H.); ze.zhang001@gmail.com (Z.Z.) \\ Department of Plant and Environmental Sciences, Faculty of Science, University of Copenhagen, \\ Højbakkegård Allé 13, DK-2630 Tåstrup, Denmark; sasa@plen.ku.dk \\ 3 Dansk Agro Aps, Snubbekorsvej 20 C, DK-2630 Tåstrup, Denmark \\ 4 College of Water Conservancy and Architecture Engineering, Tarim University, Alar 843300, China \\ 5 School of Public Administration and Law, Northeast Agriculture University, Harbin 150030, China; \\ quanfeng.li@neau.edu.cn \\ 6 Department of Environmental Sciences, COMSATS University Islamabad, Vehari 61100, Pakistan; \\ asif.naeem@cuivehari.edu.pk \\ 7 Quinoa Quality ApS, DK-4420 Regstrup, Denmark; quinoa@paradis.dk \\ * Correspondence: 119990019@taru.edu.cn (L.L.); fuqiang@neau.edu.cn (Q.F.)
}

Received: 3 June 2020; Accepted: 24 June 2020; Published: 25 June 2020

\begin{abstract}
Abiotic stresses such as drought and salinity constantly threaten food security. Biochar as a soil amendment has the potential to ameliorate soil and alleviate drought and salinity stress. Multiple studies have been conducted to evaluate the effect of biochar in alleviating independent drought or salinity stress. However, the potential of biochar in mitigating the combined drought and salinity stress on plants has not been studied so far. Therefore, a pot experiment was conducted in the climate-controlled chamber with the objective to investigate the effect of biochar on growth, physiology, and yield of quinoa under independent and combined drought and salinity stress. Quinoa plants were subjected to three irrigation treatments i.e., full irrigation (FI), deficit irrigation (DI), and alternate root-zone drying irrigation (ARD), two saline water treatments ( 0 and $400 \mathrm{mM})$ and two levels of biochar ( $0 \%$ and $5 \%$ by weight). In the FI treatment, plants were irrigated daily to maintain pot water-holding capacity. In limited irrigation treatments, $70 \%$ water of FI was applied either to the whole pot in DI or to one side of the pot alternating in ARD, respectively. The results showed that combined drought and salinity stress drastically affected growth and performance of quinoa compared to the independent drought or salinity stress. However, soil amendment with biochar had positive effect in mitigating both independent and combined effect of drought and salinity on quinoa plants. Furthermore, biochar amendment in ARD under salinity significantly enhanced plant height, shoot biomass, and grain by $11.7 \%, 18.8 \%$, and $10.2 \%$ as compared with DI under salinity, respectively. In addition, leaf photosynthetic rate $\left(\mathrm{A}_{\mathrm{n}}\right)$ and stomatal conductance $\left(\mathrm{g}_{\mathrm{s}}\right)$ decreased under limited saline irrigation. Moreover, the interactive effect of biochar and ARD efficiently adjusted the balance between chemical signal (leaf ABA) and hydraulic signal (leaf water potential). Thus, intrinsic water use efficiency (WUE $)_{\mathrm{i}}$ ) and yield in ARD were significantly enhanced compared to $\mathrm{DI}$, especially under salinity stress. Overall, biochar in combination with ARD might be a wise approach for sustaining crop productivity in salt affected and drought stressed areas of the world to ensure food security.
\end{abstract}

Keywords: drought; salinity; quinoa; alternate root-zone drying irrigation 


\section{Introduction}

Global climate change is expected to cause increased temperatures and more unevenly distributed precipitation, resulting in severe drought, heat wave, and soil salinity in arid and semi-arid areas $[1,2]$. In addition, poor irrigation management not only decreases water use efficiency but also the drought intensity. It is estimated that $30 \%$ of global land surface will experience extreme drought by the 2090s [3]. Drought stress is the most serious abiotic stress that has a direct impact on crop performance [4]. Additionally, high evaporation increases water loss, aggravating salt accumulation [5]. Soil salinity can also be induced by non-optimal irrigation strategies, resulting in crop yield reduction [6]. According to a recent survey, there is nearly 1.2 billion hectares of land is affected by salinity [7]. Drought stress along with soil salinity are the most common and frequently co-occurring abiotic stresses and threaten global food security, especially in arid and semi-arid regions of the world [8-10]. Hence, it is urgently needed to introduce synergistic approaches like smart irrigation strategies, improve soil by amendment, such as biochar or compost, and cultivation of climate resilient crops (such as quinoa) to ensure food security.

Water-saving irrigation techniques such as deficit irrigation (DI) and alternate root-zone drying irrigation (ARD) are widely investigated in many regions of the world, especially in arid and semi-arid regions [11-13]. Full irrigation (FI) supplies sufficient water to meet demand of plant performance during the whole growth period, resulting in the maximum yield. However, this method causes water loss, non-economical water use, and reduces water use efficiency (WUE), thus is unrealistic to implement especially in areas of water shortage. In contrast, DI may reduce irrigation requirements compared to FI with a minor negative effect on crop yield [14]. In ARD, irrigation was only applied to one side to soil water holding capacity each time and switched to the other side when the soil moisture of the other side decreased to a predetermined level [12]. Studies have confirmed that ARD could significantly enhance crop yield and perform a higher WUE compared with DI when the same amount of water was applied $[15,16]$. The ARD maintains the balance between chemical signal and hydraulic signal in plants $[13,17]$. In brief, roots in the drying part of the soil trigger abscisic acid (ABA) production, resulting in closing of stomatal aperture and consequently decreasing water loss through transpiration. At the same time, roots in the irrigated part absorb water to maintain plant growth $[18,19]$. In addition, earlier studies stated that ARD promotes root development and distribution, thereafter increases water and nutrient uptake, resulting in maintaining physiological activities under limited irrigation [20-22]. Moreover, multiple studies have demonstrated that stomatal conductance $\left(\mathrm{g}_{\mathrm{s}}\right)$ in ARD is reduced, while there is still much debate on effects of the photosynthesis rate $\left(A_{n}\right)$ [23-28]. Additionally, Ghrab et al. [29] reported ARD could not only decrease irrigation supplement but reduce the quantity of salt incorporated in the root-zone and thus mitigate negative effects of soil salinity.

In addition to water-saving irrigation, soil amendment such as biochar is also proven to mitigate negative effects of drought and salinity stress on crops [30]. Biochar is the carbon-rich product of thermally cracked biomass feedstock in an oxygen limited environment [31]. In addition, biochar contains substantial quantities of minerals such as calcium and magnesium and inorganic carbonates, which is beneficial for plant growth. Biochar may improve soil productivity, soil permeability, and carbon sequestration [32-36]. Zhu et al. [37] indicated that biochar could enhance yield by stimulating microbe activity in the rhizosphere and improving soil water holding capacity. Moreover, biochar significantly increased soil surface area due to its highly porous structure, resulting in enhanced cation exchange capacity (CEC) [38]. Thus, abundant amounts of nutrients could be retained in soil, increasing nutrient use efficiency, leading to higher crop yield [39]. In our earlier study, we found that biochar has the ability to increase soil moisture content mainly because of its high porosity. Moreover, we also found that biochar might have the ability to reduce salinity stress and proposed three mechanisms i.e., 1) transient binding of $\mathrm{Na}^{+}$on its exchange site, and thus reducing $\mathrm{Na}^{+}$uptake; 2) increasing $\mathrm{K}^{+}$concentration in soil solution, and thereby maintaining $\mathrm{Na}^{+} / \mathrm{K}^{+}$ionic balance to reduce $\mathrm{Na}^{+}$uptake; 3) increasing soil moisture content may causes dilution affect which ultimately may cause 
reduction in $\mathrm{Na}^{+}$uptake [40]. Additionally, biochar possesses high salt adsorption ability, thus could reduce $\mathrm{Na}^{+}$uptake in plants and alleviate the adverse impact caused by soil salinity [41-43].

Quinoa (Chenopodium quinoa Willd.) is an optimal choice as a crop with a high degree of tolerance against abiotic stresses. Quinoa originated in the Andean region of South America, where climatic and environmental conditions are harsh due to saline soils, drought, frost, and extreme temperature variations [44-48]. Recently, quinoa attracts strong interest around world due to its exceptional nutritional profile and abiotic stress tolerance [49,50]. However, quinoa production is far too insufficient to meet ever-increasing demand under extreme growing environment, particularly drought and salinity stress $[44,46]$.

The effect of biochar on improving plant performance and alleviating independent drought and salinity stress have been studied extensively [26,30,41]. However, to the best of our knowledge, no information is available about soil amendment with biochar in mitigating the combined effect of drought and salinity stress on quinoa. Therefore, the present study was conducted to study the effect of biochar in mitigating the combined drought and salinity stress of quinoa. The finding would be useful to enhance food security in the context of global climate change.

\section{Materials and Methods}

\subsection{Preparation of Biochar}

The biochar used in this experiment was produced by corn straw at $500{ }^{\circ} \mathrm{C}$ under anaerobic conditions and provided by Jinhefu Agricultural Development Co., Ltd., Liaoning, China. The basic physical and chemical properties of biochar are shown in Table 1 [51]. The biochar used in the study was alkaline in nature.

Table 1. Chemical characteristics of pure biochar applied in the experiment.

\begin{tabular}{ccc}
\hline & Unit & Value \\
\hline Particle size & $\mathrm{mm}$ & $1.5-2.0$ \\
Bulk density & $\mathrm{g} / \mathrm{cm}^{3}$ & 0.51 \\
Carbon $(\mathrm{C})$ & $\%$ & 70.38 \\
Nitrogen $(\mathrm{N})$ & $\%$ & 1.53 \\
Hydrogen $(\mathrm{H})$ & $\%$ & 1.68 \\
Sulphur $(\mathrm{S})$ & $\%$ & 0.78 \\
Ash content & $\%$ & 31.8 \\
Cation exchange capacity (CEC) & $\mathrm{cmol}(+) / \mathrm{kg}$ & 12.0 \\
Electrical conductivity (EC) & $\mathrm{mS} / \mathrm{cm}$ & 1.05 \\
pH & - & 9.14 \\
\hline
\end{tabular}

\subsection{Pot Study}

A pot experiment was conducted in climate chambers from April to July 2018 at the School of Water Conservancy and Civil Engineering, Northeast Agriculture University, Harbin, China. The climate conditions in two chambers were set as follows: temperature $24 / 20 \pm 2{ }^{\circ} \mathrm{C}$ at day/night; relative humidity $60 \pm 2 \%$; light was supplied by lamps with an average light intensity of $580-680 \mu \mathrm{mol} \mathrm{m}^{-2} \mathrm{~s}^{-1}$ for $13 \mathrm{~h}$ photoperiod. From sowing, seeds of quinoa cv. Titicaca were grown in peat-filled plastic trays in climate-controlled chambers. Four weeks later, one seedling was transplanted to plastic pots (height $10 \mathrm{~cm}$, diameter $4 \mathrm{~cm}$ ) containing $5 \mathrm{~kg}$ of sandy loam soil. Biochar was mixed in soil before filling the pots at the rate of $5 \%$ by weight. Pots lacking biochar served as controls. Fertilizers were mixed in soil at rates of $80 \mathrm{~kg} \mathrm{~N}, 30 \mathrm{~kg} \mathrm{P}, 90 \mathrm{~kg} \mathrm{~K}$, and $9 \mathrm{~kg} \mathrm{Mg} \mathrm{ha}^{-1}$. The plants were exposed to combinations of three irrigation regimes (FI, DI, and ARD), two biochar treatments $(0 \%$ and $5 \% \mathrm{w} / \mathrm{w})$ under non-saline and saline conditions ( 0 and $400 \mathrm{mM}$ ) with four replications. 


\subsection{Irrigation Treatments}

Plants were irrigated with $0 \mathrm{mM} \mathrm{NaCl}$ (tap water, non-saline) and $400 \mathrm{mM} \mathrm{NaCl}$ (saline) solution beyond one week after transplanting, respectively. $\mathrm{NaCl}$ concentration was gradually increased with $80 \mathrm{mM}$ by step until the level was reached $400 \mathrm{mM} \mathrm{NaCl}$. Meanwhile, plants were exposed to three irrigation treatments, i.e., full irrigation (FI), deficit irrigation (DI), and alternate root-zone drying irrigation (ARD). (1) In the FI regime, plants were irrigated in the whole pot to soil water holding capacity ( $30 \%$ of soil volumetric water content). (2) In the ARD regime, pots were separated into two sections equally in vertical direction and irrigation was supplied to one section to soil water holding capacity each time and then switched to the drier section when the soil moisture decreased to $10 \%$. (3) In the DI regime, plants were irrigated in the whole pot with the same amount of water in ARD. Water holding capacity (WHC) was measured as described by Priha et al. [52]. The soil moisture in pots was determined using oven drying [53].

\subsection{Growth and Yield Parameters}

At harvest, plant height was measured. Shoot biomass was collected and determined after oven drying at $70{ }^{\circ} \mathrm{C}$ until constant weight. Grains were collected and measured for 100 -grains weight and yield/plant.

\subsection{Physiological Measurements}

Leaf photosynthetic rate $\left(A_{n}\right)$ and stomatal conductance $\left(g_{s}\right)$ were measured at 10:00 to 13:00 am on upper canopy of fully mature leaves using portable photosynthetic system (LiCor-6400, LI-Cor Bioscience, $\mathrm{NE}$, USA). The measurements were performed on one leaf per pot at a $\mathrm{CO}_{2}$ concentration of $400 \mathrm{ppm}$ with $1200 \mu \mathrm{mol} \mathrm{m} \mathrm{m}^{-2} \mathrm{~s}^{-1}$ photon flux density under $28.5^{\circ} \mathrm{C}$ chamber temperature. Intrinsic water use efficiency (WUEi) was calculated by the ratio of $\mathrm{A}_{\mathrm{n}} / \mathrm{g}_{\mathrm{s}}$. Chlorophyll content index (CCI) were measured with portable leaf chlorophyll meter (CCM-200; Opti-Science, Tyngsboro, MA, USA).

\subsection{Leaf Water Potential}

Immediately, after measuring gas exchange measurement, the same leaf was detached to determine leaf water potential with a pressure chamber (3000 Series Plant Water Status Consoles, Soil Moisture Equipment Corp., Santa Barbara, CA, USA).

\subsection{Leaf Abscisic Acid (ABA)}

Leaf samples (around $30 \mathrm{mg}$ ) were crushed using mortar and pestle in liquid nitrogen and $1 \mathrm{~mL}$ of milli-Q $\mathrm{H}_{2} \mathrm{O}$. Thereafter, samples were taken in Eppendorf tubes and homogenized by shaking for $24 \mathrm{~h}$ at $4{ }^{\circ} \mathrm{C}$ and then centrifuged at $10,000 \times \mathrm{g}$ for $5 \mathrm{~min}$ at $4{ }^{\circ} \mathrm{C}$. The clear supernatant was collected and stored at $4{ }^{\circ} \mathrm{C}$ until analysis. Leaf ABA concentration in leaf samples was determined by ELISA method using a monoclonal antibody for ABA (AFRC MAC252) [54].

\subsection{Total Leaf Nitrogen and Carbon Content}

Total nitrogen and carbon contents (\%DW) from finely ground dry leaf samples were determined using an Elemental Analyzer System (vario PYRO cube, Elementar Analysensysteme GmbH, Germany).

\subsection{Leaf $\mathrm{Na}^{+}$and $\mathrm{K}^{+}$Measurement}

The dry leaf samples were ground and digested by $\mathrm{HNO}_{3}$. The concentration of $\mathrm{Na}^{+}$and $\mathrm{K}^{+}$was determined by an atomic absorption spectrometer (ICE3500, Thermo Fisher Scientific Inc., Waltham, MA, USA). 


\subsection{Statistical Analysis}

The experiment was conducted in a completely randomized design (CRD) with four replications of each treatment. The data were analyzed by three-way ANOVA using R version 3.6.3 (R Development Core Team, 2012, https://www.r-project.org) and presented as mean of replicates \pm standard error. Regression analyses were used to determine the relationship between some of the variables. Significance between treatments was analyzed at $p \leq 0.05$.

\section{Results}

\subsection{Plant Growth and Yield Responses}

Plant height, shoot biomass, and grain yield were all significantly affected by biochar (B), irrigation (I), and salinity (S) (Tables 2 and 3). Plant height was significantly affected by $\mathrm{S} \times \mathrm{I}$ and grain yield was significantly affected by both $\mathrm{B} \times \mathrm{S}$ and $\mathrm{S} \times \mathrm{I}$. Shoot biomass was unaffected by interactions. Maximum plant height, shoot biomass, and grain yield were all found in FI with biochar treatments and significantly higher than in both DI and ARD with biochar treatments under both non-saline and saline irrigations. Additionally, biochar amendment significantly enhanced plant height, shoot biomass, and grain yield by $11.7 \%, 18.8 \%$, and $10.2 \%$ in ARD with $400 \mathrm{mM}$ than DI with $400 \mathrm{mM}$, respectively.

Table 2. Growth and yield of quinoa as affected by biochar, irrigation regimes, and salinity.

\begin{tabular}{|c|c|c|c|c|c|}
\hline \multicolumn{3}{|c|}{ Treatments } & \multirow{2}{*}{$\begin{array}{c}\text { Plant Height (cm) } \\
\qquad 136.25 \pm 3.20 \mathrm{~b}\end{array}$} & \multirow{2}{*}{$\begin{array}{c}\text { Shoot Biomass (g) } \\
24.64 \pm 1.03 \mathrm{~b}\end{array}$} & \multirow{2}{*}{$\begin{array}{c}\text { Grain } \\
\text { Yield/Pot (g) } \\
14.50 \pm 0.59 \mathrm{~b}\end{array}$} \\
\hline \multirow{6}{*}{ non-saline (0 mM) } & \multirow{2}{*}{ FI } & B0 & & & \\
\hline & & B5 & $152.32 \pm 4.02 \mathrm{a}$ & $27.83 \pm 0.63 \mathrm{a}$ & $15.50 \pm 0.65 a$ \\
\hline & \multirow{2}{*}{ DI } & B0 & $109.75 \pm 2.75 \mathrm{~d}$ & $17.51 \pm 0.74 \mathrm{f}$ & $10.23 \pm 0.55 \mathrm{~d}$ \\
\hline & & B5 & $117.43 \pm 5.18 c$ & $18.39 \pm 0.77 f$ & $11.38 \pm 0.90 c$ \\
\hline & \multirow{2}{*}{ ARD } & B0 & $119.75 \pm 3.12 c$ & $19.93 \pm 0.50 \mathrm{e}$ & $11.25 \pm 0.48 \mathrm{~d}$ \\
\hline & & B5 & $131.23 \pm 2.50 \mathrm{~b}$ & $21.84 \pm 0.62 \mathrm{~d}$ & $12.43 \pm 0.34 c$ \\
\hline \multirow{6}{*}{ Saline $(400 \mathrm{mM})$} & \multirow{2}{*}{ FI } & B0 & $68.00 \pm 1.67 \mathrm{f}$ & $20.42 \pm 0.85 \mathrm{~d}$ & $5.10 \pm 0.21 \mathrm{e}$ \\
\hline & & B5 & $76.16 \pm 2.01 \mathrm{e}$ & $23.06 \pm 0.52 c$ & $5.45 \pm 0.23 \mathrm{e}$ \\
\hline & \multirow{2}{*}{ DI } & B0 & $54.88 \pm 1.38 \mathrm{~h}$ & $14.51 \pm 0.61 \mathrm{~h}$ & $3.60 \pm 0.20 h$ \\
\hline & & B5 & $58.72 \pm 2.59 \mathrm{~g}$ & $15.23 \pm 0.64 \mathrm{~h}$ & $3.90 \pm 0.12 \mathrm{~g}$ \\
\hline & \multirow{2}{*}{ ARD } & B0 & $59.88 \pm 1.56 \mathrm{~g}$ & $16.52 \pm 0.41 \mathrm{~g}$ & $3.96 \pm 0.17 \mathrm{~g}$ \\
\hline & & B5 & $65.61 \pm 1.25 \mathrm{f}$ & $18.11 \pm 0.52 \mathrm{f}$ & $4.37 \pm 0.12 \mathrm{f}$ \\
\hline
\end{tabular}

B0 and B5 indicate biochar levels, respectively. FI, DI, and ARD indicate full irrigation, deficit irrigation, and alternate root-zone drying irrigation, respectively. Lowercase letters indicate significant differences between treatments.

Table 3. Output of three-way ANOVA for leaf photosynthetic rate (A.n), stomatal conductance $\left(\mathrm{g}_{\mathrm{s}}\right)$, intrinsic water use efficiency $\left(\mathrm{WUE}_{\mathrm{i}}\right)$, leaf water potential $\left(\Psi_{\text {leaf }}\right)$, leaf abscisic acid $(\mathrm{ABA})$, chlorophyll content index $(\mathrm{CCI})$, leaf nitrogen content $(\mathrm{N})$, leaf carbon content $(\mathrm{C})$, leaf $\mathrm{Na}^{+}$concentration, leaf $\mathrm{K}^{+}$ concentration, plant height, shoot biomass, and grain yield of quinoa as affected by biochar, irrigation regimes, and salinity.

\begin{tabular}{cccccccccccccc}
\hline Factors & $\mathbf{A}_{\mathbf{n}}$ & $\mathbf{g}_{\mathbf{s}}$ & WUE $_{\mathbf{i}}$ & $\mathbf{\Psi}_{\text {leaf }}$ & $\begin{array}{c}\text { Leaf } \\
\text { ABA }\end{array}$ & $\mathbf{C C I}$ & $\mathbf{N}$ & $\mathbf{C}$ & $\mathbf{N a}^{+}$ & $\mathbf{K}^{+}$ & $\begin{array}{c}\text { Plant } \\
\text { Height }\end{array}$ & $\begin{array}{c}\text { Shoot } \\
\text { Biomass }\end{array}$ & $\begin{array}{c}\text { Grain } \\
\text { Yield }\end{array}$ \\
\hline $\mathrm{B}$ & $* * *$ & $* * *$ & $* * *$ & $* * *$ & $* * *$ & $* * *$ & $* * *$ & $\mathrm{~ns}$ & $* * *$ & $* * *$ & $* * *$ & $* * *$ & $* * *$ \\
$\mathrm{I}$ & $* * *$ & $* * *$ & $* * *$ & $* * *$ & $* * *$ & $* * *$ & $* * *$ & $\mathrm{~ns}$ & $* * *$ & $* * *$ & $* * *$ & $* * *$ & $* * *$ \\
$\mathrm{~S}$ & $* * *$ & $* * *$ & $* * *$ & $* * *$ & $* * *$ & $* * *$ & $* * *$ & $* * *$ & $* * *$ & $* * *$ & $* * *$ & $* * *$ & $* * *$ \\
$\mathrm{~B} \times \mathrm{I}$ & $\mathrm{ns}$ & $* *$ & $*$ & $\mathrm{~ns}$ & $* * *$ & $\mathrm{~ns}$ & $* *$ & $\mathrm{~ns}$ & $\mathrm{~ns}$ & $*$ & $\mathrm{~ns}$ & $\mathrm{~ns}$ & $\mathrm{~ns}$ \\
$\mathrm{~B} \times \mathrm{S}$ & $\mathrm{ns}$ & $* * *$ & $\mathrm{~ns}$ & $\mathrm{~ns}$ & $\mathrm{~ns}$ & $* * *$ & $*$ & $\mathrm{~ns}$ & $* * *$ & $\mathrm{~ns}$ & $\mathrm{~ns}$ & $\mathrm{~ns}$ & $* *$ \\
$\mathrm{~S} \times \mathrm{I}$ & $* * *$ & $* * *$ & $* *$ & $*$ & $* * *$ & $* * *$ & $\mathrm{~ns}$ & $\mathrm{~ns}$ & $* * *$ & $* *$ & $* *$ & $\mathrm{~ns}$ & $* * *$ \\
$\mathrm{~S} \times \mathrm{B} \times \mathrm{I}$ & $\mathrm{ns}$ & $\mathrm{ns}$ & $\mathrm{ns}$ & $\mathrm{ns}$ & $\mathrm{ns}$ & $\mathrm{ns}$ & $\mathrm{ns}$ & $\mathrm{ns}$ & $\mathrm{ns}$ & $\mathrm{ns}$ & $\mathrm{ns}$ & $\mathrm{ns}$ & $\mathrm{ns}$ \\
\hline
\end{tabular}

$\mathrm{B}, \mathrm{I}$, and $\mathrm{S}$ indicate biochar, irrigation, and salinity. $\mathrm{B} \times \mathrm{I}, \mathrm{B} \times \mathrm{S}, \mathrm{S} \times \mathrm{I}$, and $\mathrm{S} \times \mathrm{B} \times \mathrm{I}$ indicate interactions among biochar, irrigation, and salinity. ${ }^{*}, * *$ and ${ }^{* * *}$ indicate significant levels at $p<0.05, p<0.01$, and $p<0.001$, respectively; ns denotes no significance. 


\subsection{Physiological Responses}

The influence of $B, I$, and $S$ on leaf photosynthetic rate $\left(A_{n}\right)$, stomatal conductance $\left(g_{s}\right)$, and $W U E_{i}$ were shown in Figure 1 and Table 3. Regardless of $S$ and B, reduced irrigation (DI and ARD) significantly decreased both $A_{n}$ and $g_{s}$ compared to FI. Biochar amendment performed positively effects on both $A_{n}$ and $g_{s}$ in all irrigation regimes, especially in ARD under salinity irrigation. There were remarkable significant interactions $(B \times I, B \times S, S \times I)$ for $g_{s}$, while $A_{n}$ was only significantly affected by $S \times I$. Across ARD treatments under saline irrigation, $\mathrm{A}_{\mathrm{n}}$ and $\mathrm{g}_{\mathrm{s}}$ were $17.3 \%$ and $37.0 \%$ higher in $\mathrm{B} 5$ plants as compared with B0 plants, respectively. Moreover, maximum WUE $\mathrm{i}_{\mathrm{i}}$ was observed in ARD, B5, and saline treatment.

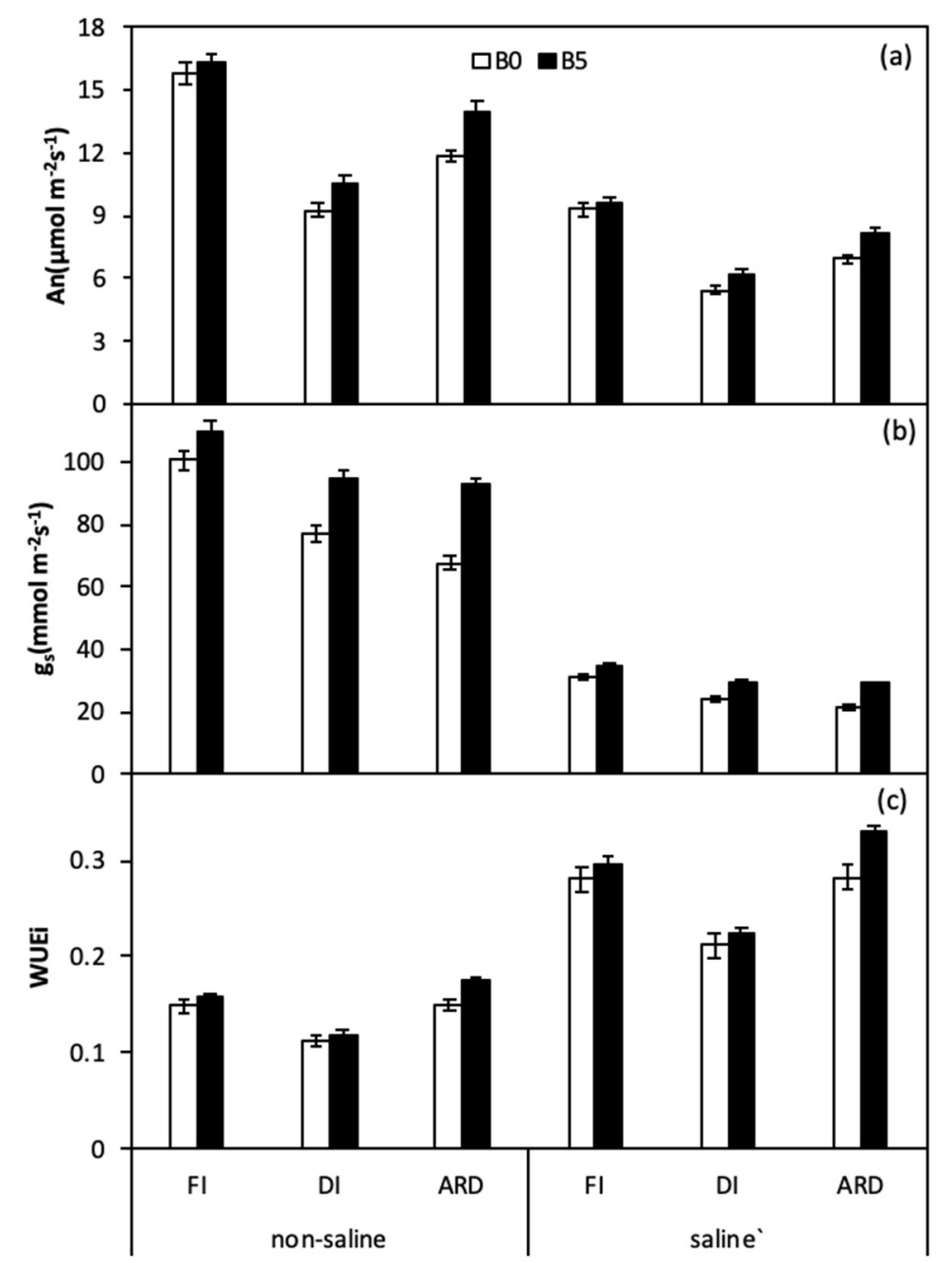

Figure 1. Leaf photosynthesis $\left(A_{n}\right)(a)$, stomatal conductance $\left(g_{s}\right)(b)$, and intrinsic water use efficiency $\left(\mathrm{WUE}_{\mathrm{i}}\right)(\mathbf{c})$, of quinoa leaves as affected by biochar, irrigation regimes, and salinity. B0 and B5 indicate biochar levels, respectively. FI, DI, and ARD indicate full irrigation, deficit irrigation, and alternate root-zone drying irrigation, respectively. Error bars indicate $\pm \mathrm{SE}(n=4)$. SE indicates standard error.

\subsection{Leaf Water Potential and Leaf Abscisic Acid Concentration}

The effects of B, I, and S on leaf water potential $\left(\psi_{\text {leaf }}\right)$ and leaf abscisic acid (ABA) concentration are presented in Figure 2 and Table 3. $\psi_{\text {leaf }}$ was significantly affected by B, I, S, and S $\times$ I; meanwhile, ABA was significantly affected by $B, I, S, B \times I$, and $S \times I$. Regardless of $S$ and $B$, reduced irrigation significantly decreased $\psi_{\text {leaf }}$ (more negative) and increased ABA. However, $B$ had significant positive effect on $\psi_{\text {leaf }}$ and ABA. Furthermore, B showed better performance in ARD on enhancing $\psi_{\text {leaf }}$ and reducing $\mathrm{ABA}$ as compared with DI under saline irrigation. Meanwhile, there were no significant 
differences between biochar and without biochar on $\psi_{\text {leaf }}$ and ABA in FI under both non-saline and saline irrigation.

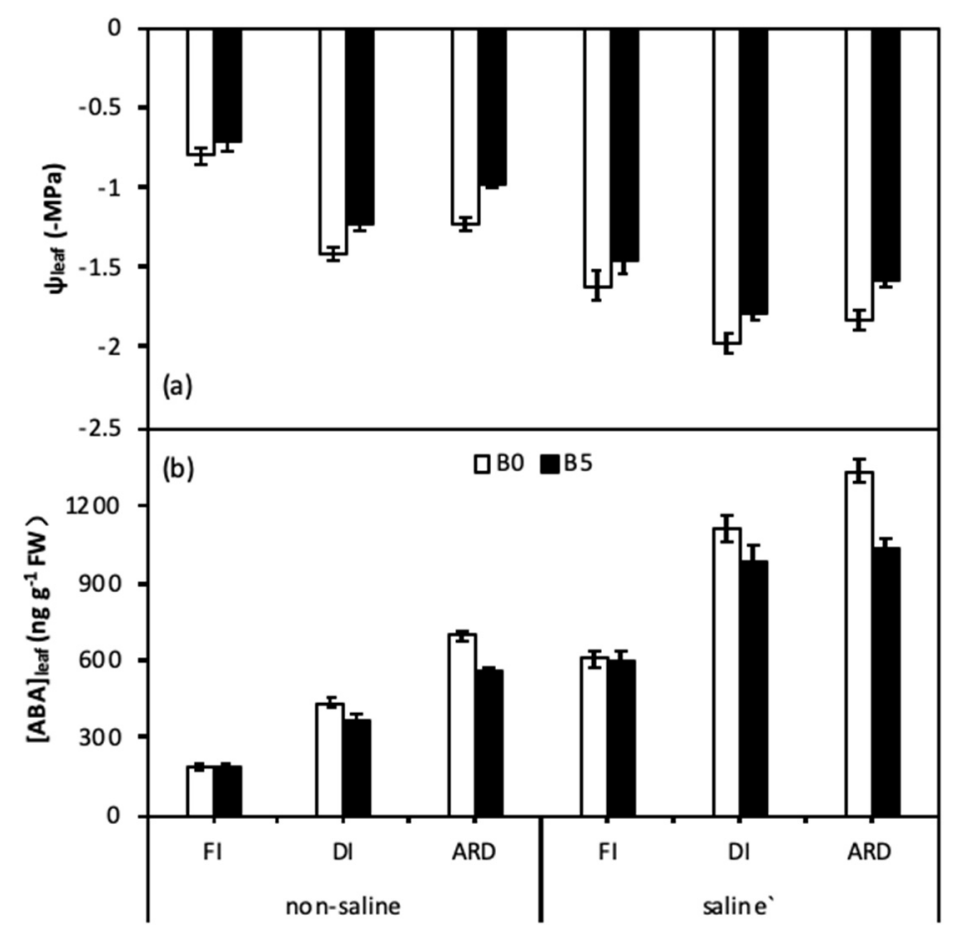

Figure 2. Total leaf water potential ( $\left.\Psi_{\text {leaf }}\right)(\mathbf{a})$ and abscisic acid (ABA) concentrations $(\mathbf{b})$ of quinoa leaves as affected by biochar, irrigation regimes, and salinity. B0 and B5 indicate biochar levels, respectively. FI, DI, and ARD indicate full irrigation, deficit irrigation, and alternate root-zone drying irrigation, respectively. Error bars indicate $\pm \mathrm{SE}(n=4)$. SE indicates standard error.

\subsection{Chlorophyll Content Index, Leaf $N$, and $C$}

Chlorophyll content index (CCI) was significantly affected by B, I, S, B $\times$ S, and S $\times$ I (Figure 3a, Table 3). Across I treatments under saline conditions, CCI was $20.0 \%, 22.1 \%$, and $26.5 \%$ higher in B0 compared with B5, respectively. Leaf $\mathrm{N}$ content was significantly affected by B, I, S, B $\times \mathrm{I}$, and B $\times \mathrm{S}$ (Figure 3b, Table 3). Regardless of $\mathrm{S}$ and I, leaf N in B5 was significantly lower than in B0. Leaf C content was solely affected by salinity (Figure 3c, Table 3). Regardless of B and S, CCI and leaf N in ARD were both higher than in DI.

\subsection{Leaf $\mathrm{Na}^{+}$and $\mathrm{K}^{+}$}

The effects of $\mathrm{B}, \mathrm{I}$, and $\mathrm{S}$ on leaf $\mathrm{Na}^{+}$and $\mathrm{K}^{+}$are shown in Figure 4 and Table 3. Leaf $\mathrm{Na}^{+}$was significantly affected by B, I, S, B $\times$ S, and S $\times$ I and leaf $\mathrm{K}+$ significantly affected by B, I, S, B $\times$ I, and S $\times$ I. Across I and saline treatments, leaf $\mathrm{Na}^{+}$was higher and leaf $\mathrm{K}^{+}$was lower in FI than these in DI and ARD; meanwhile, leaf $\mathrm{Na}^{+}$in ARD with $\mathrm{B}$ was lower than in DI, whereas leaf $\mathrm{K}^{+}$was higher. Thus, the $\mathrm{K}^{+} / \mathrm{Na}^{+}$ratio was also enhanced by the combined strategies of $\mathrm{B}$ and ARD under saline irrigation. 


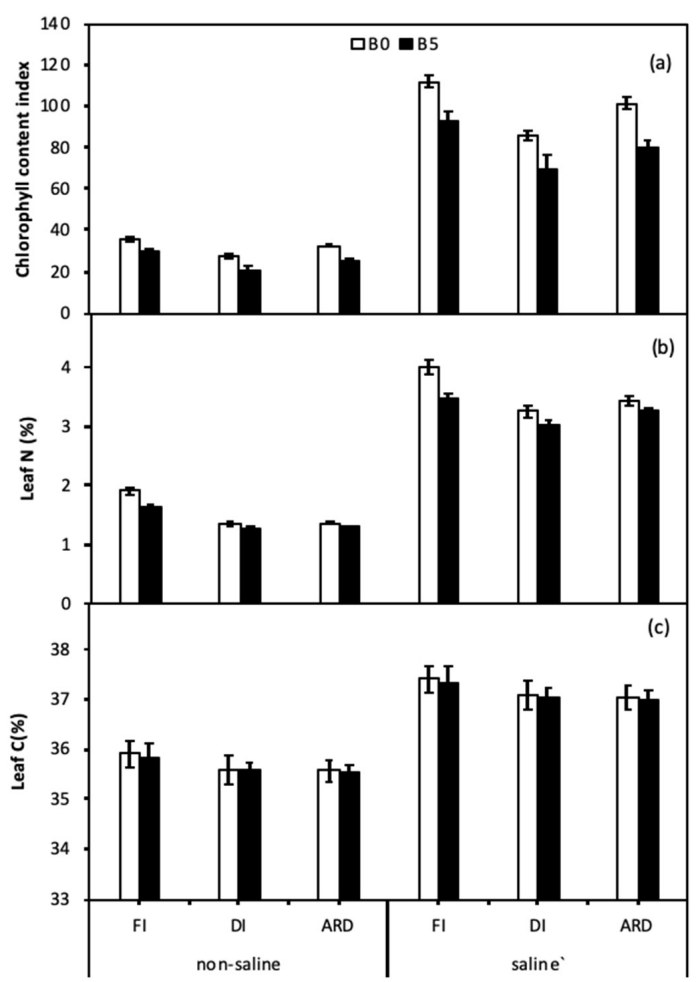

Figure 3. Leaf chlorophyll content index (a), Leaf $N(\mathbf{b})$, and $C$ (c) content as affected by biochar, irrigation regimes, and salinity. B0 and B5 indicate biochar levels, respectively. FI, DI, and ARD indicate full irrigation, deficit irrigation, and alternate root-zone drying irrigation, respectively. Error bars indicate $\pm \mathrm{SE}(n=4)$. SE indicates standard error.

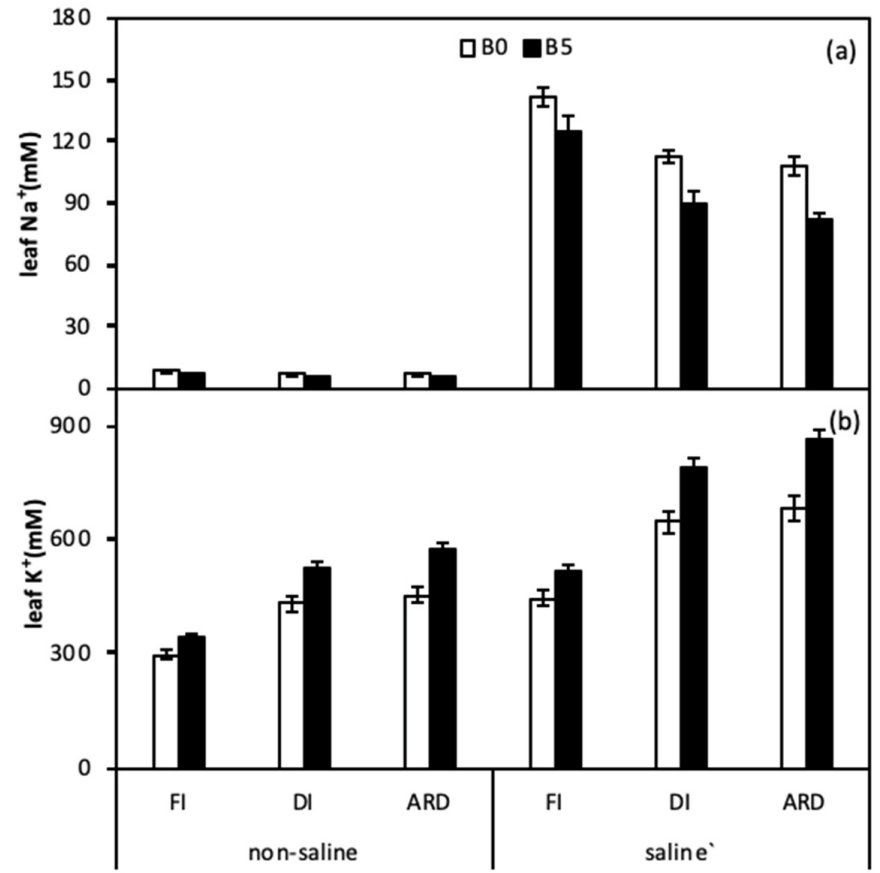

Figure 4. Leaf $\mathrm{Na}^{+}(\mathbf{a})$ and Leaf $\mathrm{K}^{+}(\mathbf{b})$ as affected by biochar, irrigation regimes, and salinity. B0 and B5 indicate biochar levels, respectively. FI, DI, and ARD indicate full irrigation, deficit irrigation, and alternate root-zone drying irrigation, respectively. Error bars indicate $\pm \mathrm{SE}(n=4)$. SE indicates standard error. 


\section{Discussion}

Drought and salinity have negative impacts on plant growth, development, and metabolism during the whole crop life cycle. Therefore, there is an urgent need to find practical and effective strategies to maintain moderate soil moisture, water supply, and ion balance for crops under drought and salinity stress. Different approaches such as water-saving irrigation techniques, biochar amendment, and planting halophyte crops such as quinoa have been used to cope with drought and salinity stresses. However, their combinative effect on drought and salinity stresses need to be further tested.

In previous studies, Akhtar et al. [30] reported that biochar enhanced soil moisture in all irrigation regimes, however, it performed a more positive impact on soil water content, especially under DI and ARD as compared with FI. Biochar application could decrease the soil bulk density and increase soil surface area due to its porous structure, resulting in enhancing the ability to absorb and retain water [43]. In addition, Baiamonte et al. [55] stated that biochar could enhance soil aggregate stability and thus promote soil moisture retention efficiently under drought stress. Similarly, Artiola et al. [56] reported that biochar porous structure reduced evapotranspiration and increased aeration and soil water holding capacity (WHC). Moreover, Akhtar et al. [26] reported that biochar could enhance soil water content and dilute ions concentration under salinity stress, thereby maintain a suitable soil environment for plant growth.

An appropriate soil water environment is the prerequisite for ensuring beneficial development of crops, especially under abiotic stress. In this study, biochar increased quinoa yield in all irrigation treatments under salinity stress (Table 2). However, application of biochar may also lead to yield reduction. Kishimoto et al. [57] reported that biochar caused a soil pH increase, accompanied with decreased micronutrient availability, resulting in soybean yield reduction. Lentz and Ippolito [58] stated biochar applied to a desert soil caused yield decline. It is worth mentioning that biochar amendment could negatively affect yield, the soil characteristics. Therefore, properties of biochar should be taken into account before adding to soil.

Abiotic stress has an extensive influence on physiological responses such as reducing leaf photosynthetic rate $\left(A_{n}\right)$ and stomatal conductance $\left(g_{s}\right)$ [59]. Similar to this, in the present study, $A_{n}$ and $g_{s}$ both significantly decreased under limited irrigation (DI and ARD) compared to FI and sharply dropped further under salinity stress, while biochar caused positive effects on $A_{n}$ and $g_{s}$ under both non-saline and saline irrigation (Figure 1). It might be because biochar not only increases soil water content but adsorbs excess $\mathrm{Na}^{+}$, thus ameliorating plant water status $[30,42,60]$. Additionally, the dry zone of ARD triggered more leaf ABA accumulation than DI, thus induced lower $g_{s}$ in ARD than DI. This is also corroborated by analysis in the present study, where we found a negative correlation between ABA and $g_{s}$ (Figure 5). Meanwhile, ARD showed much better water adjustment ability, resulting in less negative leaf water potential $\left(\psi_{\text {leaf }}\right)$ than DI. It was worth noting that biochar and ARD combined treatment had the highest intrinsic water use efficiency $\left(\mathrm{WUE}_{\mathrm{i}}\right)$ under salinity irrigation (Figure 1c).

Plants trigger dehydration avoidance mechanisms to sustain water status in drought and salinity condition $[61,62]$. ABA plays a role as an important chemical signal communicated between the root and leaf via the xylem stream to control stomata closure and avoid water loss under abiotic stress [63]. Plants decrease $\psi_{\text {leaf }}$ to sustain water uptake and maintain cell turgor [28]. In our study, increased available water content in soil induced by biochar effectively improved plant water status and thus increased $\psi_{\text {leaf }}$ (Figure 2). This positive effect was even amplified under ARD compared with DI. The reason is that ARD decreased ions accumulation in soil, thus reducing $\mathrm{Na}^{+}$uptake by plants (Figure 4) [29,64]. This phenomenon was also due to better control of ARD on the balance between chemical and hydraulic signals. This provided additional evidence that ARD irrigation strategy performs better than DI. It is notable that biochar could adsorb excess $\mathrm{Na}^{+}$in soil and alleviate osmotic stress [41]. Consistent with this, our results showed biochar amendment lead to reduced $\mathrm{Na}^{+}$uptake and increased $\mathrm{K}^{+}$uptake in all irrigation regimes. 


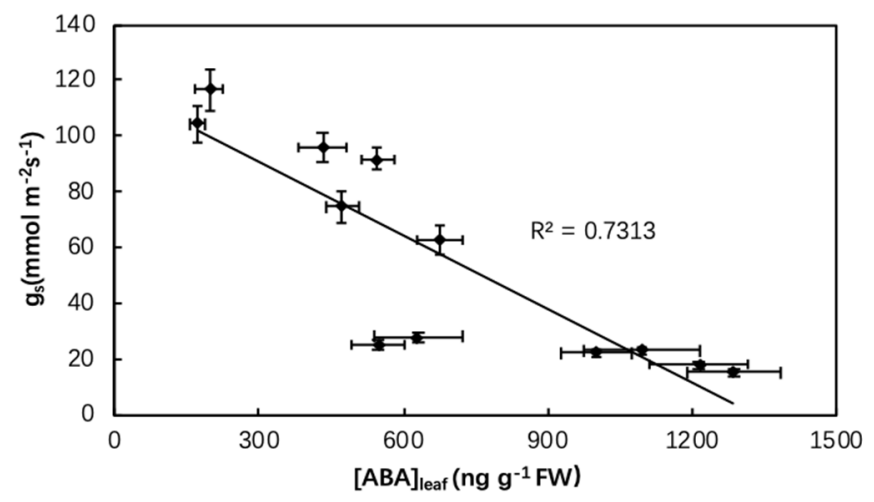

Figure 5. Relationship between stomatal conductance $\left(\mathrm{g}_{\mathrm{s}}\right)$ and abscisic acid (ABA) concentrations of quinoa leaves as affected by biochar, irrigation regimes, and salinity.

The effect of biochar in reducing salinity stress has been well documented. In our previous study, we proposed three possible mechanisms indicating how biochar may ameliorate salinity stress in plants [40]. First, biochar may have a high capacity to transiently adsorb $\mathrm{Na}^{+}$on its exchange site, resulting in lowering $\mathrm{Na}^{+}$equilibrium concentration in soil solution. Second, higher moisture retaining capacity of biochar may cause dilution of salt and thereby reduce osmotic stress. Third, biochar may increase mineral content in soil solution by releasing particularly $\mathrm{K}^{+}, \mathrm{Ca}^{2+}$, and $\mathrm{Mg}^{2+}$, which may consequently have an effect in reducing $\mathrm{Na}^{+}$uptake in plants. In the current study, we also found that biochar had a significant effect in ameliorating salinity stress in plants under normal as well as limited irrigation regimes.

Biochar is also involved in the soil nitrogen cycle, such as nitrification and plant $\mathrm{N}$ uptake. Taghizadeh-Toosi et al. [65] mentioned that biochar could inhibit nitrification and increase ammonia absorption. Additionally, Clough and Condron [66] indicated that biochar may enhance ammonium storage capacity of soil and decrease nitrate leaching. In our case, leaf $\mathrm{C}$ and $\mathrm{N}$ content both deceased under limited irrigation compared with FI and both increased under salinity stress, while biochar showed obvious negative effects on leaf $\mathrm{N}$ absorption in all irrigation regimes (Figure 3). Biochar could induce soil $\mathrm{N}$ immobilization and decrease $\mathrm{N}$ availability due to the high $\mathrm{C} / \mathrm{N}$ ratio of biochar $[67,68]$. In addition, an improper amount of biochar also caused nutrient immobilization [69]. However, there is still much debate on the effect of biochar on $\mathrm{N}$ absorption of crops. Despite the high $\mathrm{C} / \mathrm{N}$ ratio of biochar amendment, organic $\mathrm{C}$ in biochar is difficult to mineralize and thus $\mathrm{N}$ immobilization could be negligible. Manzoor et al. [70] reported that biochar particle size and feedstock types could impact crop N accumulation and even cause opposite effects. Furthermore, CCI was also decreased, accompanied with reduced leaf $\mathrm{N}$ in the present study (Figure 6). It is consistent with previous studies that chlorophyll content is an important indicator, which could reflect crop nitrogen nutrition status [30].

Although leaf $\mathrm{N}$ content decreased, we still detected high yield in biochar amendments. Meanwhile, ARD is better than DI in terms of $\mathrm{N}$ uptake under both non-saline and saline irrigation. This phenomenon occurs as a result of biochar and ARD. On the one hand, biochar could efficiently increase soil fertilization and enhance the efficiency of plant nutrient uptake [71]. The improvement of CEC induced by biochar addition could optimize soil fertilizer retention and supply performance and thus elevate availability of nutrients for crops in the soil [72,73]. On the other hand, biochar and ARD maintained crop water uptake and improved plant physiology [30]. 


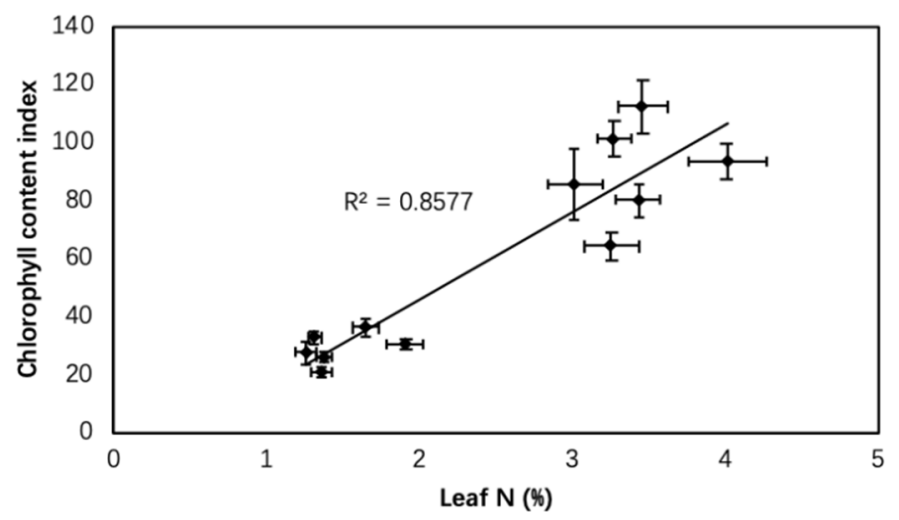

Figure 6. Relationship between chlorophyll content index (CCI) and leaf N content as affected by biochar, irrigation regimes, and salinity.

\section{Conclusions}

In conclusion, biochar could increase soil water content and thus ameliorate plant water status. In addition, biochar could adsorb excess $\mathrm{Na}^{+}$under salinity stress. These positive effects were further amplified under ARD, compared with DI. ARD showed much better water adjustment ability than DI. Biochar in combination with reduced irrigation regimes, especially ARD under salinity stress, improved photosynthesis, water relations, and growth of quinoa. However, the amount and properties of biochar should be taken into account when applied in soil. The mechanism caused by ARD and biochar not only increased ABA production and also maintained water supply and ionic balance, thus securing higher $\mathrm{WUE}_{\mathrm{i}}$ and yield for crops under salinity stress. Though biochar showed obvious negative effects on $\mathrm{N}$ absorption, biochar could increase availability of nutrients and plant nutrient uptake. Therefore, application of ARD and biochar amendment could be a wise approach for alleviating salinity stress and enhancing water use efficiency and crop productivity in arid and semi-arid areas, when growing the salinity tolerant species quinoa.

Author Contributions: Conceptualization, A.Y., L.L. and S.S.A.; methodology, A.Y.; formal analysis, A.Y., X.H. and Z.Z.; writing —original draft preparation, A.Y., S.S.A; writing-review and editing, A.Y., S.S.A., L.L., Q.F., Q.L., M.A.N., X.H., Z.Z. and S.-E.J.; supervision, Q.F. All authors have read and agreed to the published version of the manuscript.

Funding: This research was financially supported by the following grants: National Natural Science Foundation of China (51809041); China Postdoctoral Science Foundation Project (2018M641794); Heilongjiang Provincial Postdoctoral Funding Project (LBH-Z17008); Northeast Agricultural University "Youth Talent" Fund Project (18QC30).

Conflicts of Interest: The authors declare no conflict of interest.

\section{References}

1. Trenberth, K.E.; Dai, A.G.; van der Schrier, G.; Jones, P.D.; Barichivich, J.; Briffa, K.R.; Sheffield, J. Global warming and changes in drought. Nat. Clim. Chang. 2014, 4, 17-22. [CrossRef]

2. Yang, A.; Akhtar, S.S.; Iqbal, S.; Amjad, M.; Naveed, M.; Zahir, Z.A.; Jacobsen, S.-E. Enhancing salt tolerance in quinoa by halotolerant bacterial inoculation. Funct. Plant Biol. 2016, 43, 632-642. [CrossRef]

3. Burke, E.J.; Brown, S.J.; Christidis, N. Modeling the recent evolution of global drought and projections for the twenty-first century with the hadley centre climate model. J. Hydrometeorol. 2006, 7, 1113-1125. [CrossRef]

4. Cruz de Carvalho, M.H. Drought stress and reactive oxygen species: Production, scavenging and signaling. Plant Signal. Behav. 2008, 3, 156-165. [CrossRef] [PubMed]

5. Gran, M.; Carrera, J.; Olivella, S.; Saaltink, M.W. Modeling evaporation processes in a saline soil from saturation to oven dry conditions. Hydrol. Earth Sys. Sci. 2011, 15, 2077-2089. [CrossRef]

6. Dehaan, R.L.; Taylor, G.R. Field-derived spectra of salinized soils and vegetation as indicators of irrigationinduced soil salinization. Remote Sens. Environ. 2002, 80, 406-417. [CrossRef] 
7. FAO. The Future of Food and Agriculture: Trends and Challenges; Food and Agriculture Organization of the United Nations: Rome, Italy, 2017.

8. Zhu, J.-K. Abiotic Stress Signaling and Responses in Plants. Cell 2016, 167, 313-324. [CrossRef] [PubMed]

9. Suzuki, N.; Rivero, R.M.; Shulaev, V.; Blumwald, E.; Mittler, R. Abiotic and biotic stress combinations. New Phytol. 2014, 203, 32-43. [CrossRef]

10. Bargaz, A.; Nassar, R.M.A.; Rady, M.M.; Gaballah, M.S.; Thompson, S.M.; Brestic, M.; Schmidhalter, U.; Abdelhamid, M.T. Improved Salinity Tolerance by Phosphorus Fertilizer in Two Phaseolus vulgaris Recombinant Inbred Lines Contrasting in Their P-Efficiency. J. Agron. Crop. Sci. 2016, 202, 497-507. [CrossRef]

11. Chai, Q.; Gan, Y.T.; Zhao, C.; Xu, H.L.; Waskom, R.M.; Niu, Y.N.; Siddique, K.H.M. Regulated deficit irrigation for crop production under drought stress. A review. Agron. Sustain. Dev. 2016, 36, 21. [CrossRef]

12. Kang, S.Z.; Zhang, J.H. Controlled alternate partial root-zone irrigation: Its physiological consequences and impact on water use efficiency. J. Exp. Bot. 2004, 55, 2437-2446. [CrossRef] [PubMed]

13. Sepaskhah, A.R.; Ahmadi, S.H. A Review on Partial Root-Zone Drying Irrigation. Int. J. Plant Prod. 2010, 4, 241-258.

14. English, M.; Raja, S.N. Perspectives on deficit irrigation. Agr. Water Manag. 1996, 32, 1-14. [CrossRef]

15. Wang, Z.C.; Liu, F.L.; Kang, S.Z.; Jensen, C.R. Alternate partial root-zone drying irrigation improves nitrogen nutrition in maize (Zea mays L.) leaves. Environ. Exp. Bot. 2012, 75, 36-40. [CrossRef]

16. Sun, Y.; Holm, P.E.; Liu, F. Alternate partial root-zone drying irrigation improves fruit quality in tomatoes. Hortic. Sci. 2014, 41, 185-191. [CrossRef]

17. De Lima, R.S.N.; Figueiredo, F.; Martins, A.O.; de Deus, B.C.D.; Ferraz, T.M.; Gomes, M.D.D.; de Sousa, E.F.; Glenn, D.M.; Campostrini, E. Partial rootzone drying (PRD) and regulated deficit irrigation (RDI) effects on stomatal conductance, growth, photosynthetic capacity, and water-use efficiency of papaya. Sci. Hortic. Amst. 2015, 183, 13-22. [CrossRef]

18. Liu, F.L.; Shahnazari, A.; Andersen, M.N.; Jacobsen, S.E.; Jensen, C.R. Physiological responses of potato (Solanum tuberosum L.) to partial root-zone drying: ABA signalling, leaf gas exchange, and water use efficiency. J. Exp. Bot. 2006, 57, 3727-3735. [CrossRef]

19. Wang, H.Q.; Liu, F.L.; Andersen, M.N.; Jensen, C.R. Comparative effects of partial root-zone drying and deficit irrigation on nitrogen uptake in potatoes (Solanum tuberosum L.). Irrig. Sci. 2009, 27, 443-448. [CrossRef]

20. Benjamin, J.G.; Nielsen, D.C. Water deficit effects on root distribution of soybean, field pea and chickpea. Field Crop. Res. 2006, 97, 248-253. [CrossRef]

21. Wang, F.X.; Kang, Y.H.; Liu, S.P. Effects of drip irrigation frequency on soil wetting pattern and potato growth in North China Plain. Agric. Water Manag. 2006, 79, 248-264. [CrossRef]

22. Gaur, P.M.; Krishnamurthy, L.; Kashiwagi, J. Improving drought-avoidance root traits in chickpea (Cicer arietinum L.) - Current status of research at ICRISAT. Plant Prod. Sci. 2008, 11, 3-11. [CrossRef]

23. Du, T.; Kang, S.; Zhang, J.; Li, F. Water use and yield responses of cotton to alternate partial root-zone drip irrigation in the arid area of north-west China. Irrig. Sci. 2008, 26, 147-159. [CrossRef]

24. Ahmadi, S.H.; Andersen, M.N.; Plauborg, F.; Poulsen, R.T.; Jensen, C.R.; Sepaskhah, A.R.; Hansen, S. Effects of irrigation strategies and soils on field-grown potatoes: Gas exchange and xylem ABA. Agric. Water Manag. 2010, 97, 1486-1494. [CrossRef]

25. Liu, F.L.; Shahnazari, A.; Andersen, M.N.; Jacobsen, S.E.; Jensen, C.R. Effects of deficit irrigation (DI) and partial root drying (PRD) on gas exchange, biomass partitioning, and water use efficiency in potato. Sci. Hortic. 2006, 109, 113-117. [CrossRef]

26. Akhtar, S.S.; Andersen, M.N.; Naveed, M.; Zahir, Z.A.; Liu, F.L. Interactive effect of biochar and plant growth-promoting bacterial endophytes on ameliorating salinity stress in maize. Funct. Plant Biol. 2015, 42, 770-781. [CrossRef]

27. Wang, Y.S.; Liu, F.L.; Jensen, L.S.; de Neergaard, A.; Jensen, C.R. Alternate partial root-zone irrigation improves fertilizer-N use efficiency in tomatoes. Irrig. Sci. 2013, 31, 589-598. [CrossRef]

28. Yang, A.; Akhtar, S.S.; Amjad, M.; Iqbal, S.; Jacobsen, S.E. Growth and Physiological Responses of Quinoa to Drought and Temperature Stress. J. Agron. Crop. Sci. 2016, 202, 445-453. [CrossRef]

29. Ghrab, M.; Gargouri, K.; Bentaher, H.; Chartzoulakis, K.; Ayadi, M.; Ben Mimoun, M.; Masmoudi, M.M.; Ben Mechlia, N.; Psarras, G. Water relations and yield of olive tree (cv. Chemlali) in response to partial root-zone drying (PRD) irrigation technique and salinity under arid climate. Agr. Water Manag. 2013, 123, 1-11. [CrossRef] 
30. Akhtar, S.S.; Li, G.T.; Andersen, M.N.; Liu, F.L. Biochar enhances yield and quality of tomato under reduced irrigation. Agric. Water Manag. 2014, 138, 37-44. [CrossRef]

31. Harris, P. On charcoal. Interdiscip. Sci. Rev. 1999, 24, 301-306. [CrossRef]

32. Lehmann, J.; Rillig, M.C.; Thies, J.; Masiello, C.A.; Hockaday, W.C.; Crowley, D. Biochar effects on soil biota-a review. Soil Biol. Biochem. 2011, 43, 1812-1836. [CrossRef]

33. Gomez, J.D.; Denef, K.; Stewart, C.E.; Zheng, J.; Cotrufo, M.F. Biochar addition rate influences soil microbial abundance and activity in temperate soils. Eur. J. Soil Sci. 2014, 65, 28-39. [CrossRef]

34. Leng, L.; Huang, H.; Li, H.; Li, J.; Zhou, W. Biochar stability assessment methods: A review. Sci. Total Environ. 2019, 647, 210-222. [CrossRef] [PubMed]

35. Thi Thu Nhan, N.; Xu, C.-Y.; Tahmasbian, I.; Che, R.; Xu, Z.; Zhou, X.; Wallace, H.M.; Bai, S.H. Effects of biochar on soil available inorganic nitrogen: A review and meta-analysis. Geoderma 2017, 288, 79-96.

36. Antala, M.; Sytar, O.; Rastogi, A.; Brestic, M. Potential of Karrikins as Novel Plant Growth Regulators in Agriculture. Plants 2020, 9, 43. [CrossRef]

37. Zhu, X.; Chen, B.; Zhu, L.; Xing, B. Effects and mechanisms of biochar-microbe interactions in soil improvement and pollution remediation: A review. Environ. Pollut. 2017, 227, 98-115. [CrossRef]

38. Atkinson, C.J.; Fitzgerald, J.D.; Hipps, N.A. Potential mechanisms for achieving agricultural benefits from biochar application to temperate soils: A review. Plant Soil 2010, 337, 1-18. [CrossRef]

39. Lehmann, J. Bio-energy in the black. Front. Ecol. Environ. 2007, 5, 381-387. [CrossRef]

40. Akhtar, S.S.; Andersen, M.N.; Liu, F. Residual effects of biochar on improving growth, physiology and yield of wheat under salt stress. Agr. Water Manag. 2015, 158, 61-68. [CrossRef]

41. Akhtar, S.S.; Andersen, M.N.; Liu, F. Biochar Mitigates Salinity Stress in Potato. J. Agron. Crop. Sci. 2015, 201, 368-378. [CrossRef]

42. Saifullah; Dahlawi, S.; Naeem, A.; Rengel, Z.; Naidu, R. Biochar application for the remediation of salt-affected soils: Challenges and opportunities. Sci. Total Environ. 2018, 625, 320-335. [CrossRef] [PubMed]

43. Ali, S.; Rizwan, M.; Qayyum, M.F.; Ok, Y.S.; Ibrahim, M.; Riaz, M.; Arif, M.S.; Hafeez, F.; Al-Wabel, M.I.; Shahzad, A.N. Biochar soil amendment on alleviation of drought and salt stress in plants: A critical review. Environ. Sci. Pollut. Res. 2017, 24, 12700-12712. [CrossRef] [PubMed]

44. Adolf, V.I.; Shabala, S.; Andersen, M.N.; Razzaghi, F.; Jacobsen, S.E. Varietal differences of quinoa's tolerance to saline conditions. Plant Soil 2012, 357, 117-129. [CrossRef]

45. Jacobsen, S.E.; Liu, F.L.; Jensen, C.R. Effects of soil drying on photosynthesis and water-use efficiency of quinoa. J. Exp. Bot. 2003, 54, 9.

46. Jacobsen, S.E.; Mujica, A.; Jensen, C.R. The resistance of quinoa (Chenopodium quinoa Willd.) to adverse abiotic factors. Food Rev. Int. 2003, 19, 99-109. [CrossRef]

47. Sun, Y.; Liu, F.; Bendevis, M.; Shabala, S.; Jacobsen, S.E. Sensitivity of Two Quinoa (ChenopodiumquinoaWilld.) Varieties to Progressive Drought Stress. J. Agron. Crop. Sci. 2014, 200, 12-23. [CrossRef]

48. Razzaghi, F.; Ahmadi, S.H.; Jacobsen, S.E.; Jensen, C.R.; Andersen, M.N. Effects of Salinity and Soil-Drying on Radiation Use Efficiency, Water Productivity and Yield of Quinoa (Chenopodium quinoa Willd.). J. Agron. Crop. Sci. 2012, 198, 173-184. [CrossRef]

49. Jacobsen, S.E.; Mujica, A.; Ortiz, R. The global potential for quinoa and other Andean crops. Food Rev. Int. 2003, 19, 139-148. [CrossRef]

50. Jacobsen, S.E. The worldwide potential for quinoa (Chenopodium quinoa Willd.). Food Rev. Int. 2003, 19, 167-177. [CrossRef]

51. Fu, Q.; Zhao, H.; Li, T.X.; Hou, R.J.; Liu, D.; Ji, Y.; Zhou, Z.Q.; Yang, L.Y. Effects of biochar addition on soil hydraulic properties before and after freezing-thawing. Catena 2019, 176, 112-124. [CrossRef]

52. Priha, O.; Smolander, A. Nitrogen transformations in soil under Pinus sylvestris, Picea abies and Betula pendula at two forest sites. Soil Biol. Biochem. 1999, 31, 965-977. [CrossRef]

53. O'Kelly, B.C. Accurate Determination of Moisture Content of Organic Soils Using the Oven Drying Method. Dry. Technol. 2004, 22, 1767-1776. [CrossRef]

54. Philosophhadas, S.; Hadas, E.; Aharoni, N. Characterization and use in ELISA of a new monoclonal-antibody for quantitation of abscisic-acid in senescing rice leaves. Plant Growth Regul. 1993, 12, 71-78. [CrossRef]

55. Baiamonte, G.; De Pasquale, C.; Marsala, V.; Cimo, G.; Alonzo, G.; Crescimanno, G.; Conte, P. Structure alteration of a sandy-clay soil by biochar amendments. J. Soils Sedim. 2015, 15, 816-824. [CrossRef] 
56. Artiola, J.F.; Rasmussen, C.; Freitas, R. Effects of a Biochar-Amended Alkaline Soil on the Growth of Romaine Lettuce and Bermudagrass. Soil Sci. 2012, 177, 561-570. [CrossRef]

57. Kishimoto, S. Charcoal as a soil conditioner. Symp. For. Prod. Res. Int. Achiev. Future 1985, 5, 12-23.

58. Lentz, R.D.; Ippolito, J.A. Biochar and Manure Affect Calcareous Soil and Corn Silage Nutrient Concentrations and Uptake. J. Environ. Qual. 2014, 43, 775-775. [CrossRef]

59. Tahjib-Ui-Arif, M.; Sohag, A.A.; Afrin, S.; Bashar, K.K.; Afrin, T.; Mahamud, A.; Polash, M.A.S.; Hossain, M.T.; Sohel, M.A.; Brestic, M.; et al. Differential Response of Sugar Beet to Long-Term Mild to Severe Salinity in a Soil-Pot Culture. Agriculture 2019, 9, 19. [CrossRef]

60. Palansooriya, K.N.; Ok, Y.S.; Awad, Y.M.; Lee, S.S.; Sung, J.-K.; Koutsospyros, A.; Moon, D.H. Impacts of biochar application on upland agriculture: A review. J. Environ. Manag. 2019, 234, 52-64. [CrossRef]

61. Jacobsen, S.-E.; Liu, F.; Jensen, C.R. Does root-sourced ABA play a role for regulation of stomata under drought in quinoa (Chenopodium quinoa Willd.). Sci. Hortic. 2009, 122, 281-287. [CrossRef]

62. Sun, Z.W.; Ren, L.K.; Fan, J.W.; Li, Q.; Wang, K.J.; Guo, M.M.; Wang, L.; Li, J.; Zhang, G.X.; Yang, Z.Y.; et al. Salt response of photosynthetic electron transport system in wheat cultivars with contrasting tolerance. Plant Soil Environ. 2016, 62, 515-521.

63. Zhang, J.; Davies, W.J. ABA in roots amd leaves of flooded pea-plants. J. Exp. Bot. 1987, 38, 649-659. [CrossRef]

64. Degaris, K.A.; Walker, R.R.; Loveys, B.R.; Tyerman, S.D. Comparative effects of deficit and partial root-zone drying irrigation techniques using moderately saline water on ion partitioning in Shiraz and Grenache grapevines. Aust. J. Grape Wine Res. 2016, 22, 296-306. [CrossRef]

65. Taghizadeh-Toosi, A.; Clough, T.J.; Sherlock, R.R.; Condron, L.M. Biochar adsorbed ammonia is bioavailable. Plant Soil 2012, 350, 57-69. [CrossRef]

66. Clough, T.J.; Condron, L.M. Biochar and the Nitrogen Cycle: Introduction. J. Environ. Qual. 2010, 39, 1218-1223. [CrossRef]

67. Tammeorg, P.; Simojoki, A.; Makela, P.; Stoddard, F.L.; Alakukku, L.; Helenius, J. Biochar application to a fertile sandy clay loam in boreal conditions: Effects on soil properties and yield formation of wheat, turnip rape and faba bean. Plant Soil 2014, 374, 89-107. [CrossRef]

68. Zheng, H.; Wang, Z.; Deng, X.; Herbert, S.; Xing, B. Impacts of adding biochar on nitrogen retention and bioavailability in agricultural soil. Geoderma 2013, 206, 32-39. [CrossRef]

69. Jeffery, S.; Bezemer, T.M.; Cornelissen, G.; Kuyper, T.W.; Lehmann, J.; Mommer, L.; Sohi, S.P.; van de Voorde, T.F.J.; Wardle, D.A.; van Groenigen, J.W. The way forward in biochar research: Targeting trade-offs between the potential wins. Glob. Chang. Biol. Bioenerg. 2015, 7, 1-13. [CrossRef]

70. Manzoor, M.; Gul, S.; Hidayatullah, K. Influence of Biochars on Yield and Nitrogen and Phosphorus Use Efficiency of Pisum sativum under Groundwater and Wastewater Irrigation in Arid Climate. Commun. Soil Sci. Plant Anal. 2019, 50, 1563-1579. [CrossRef]

71. Zhao, X.; Wang, J.W.; Wang, S.Q.; Xing, G.X. Successive straw biochar application as a strategy to sequester carbon and improve fertility: A pot experiment with two rice/wheat rotations in paddy soil. Plant Soil 2014, 378, 279-294. [CrossRef]

72. Lehmann, J. A handful of carbon. Nature 2007, 447, 143-144. [CrossRef] [PubMed]

73. Steiner, C.; Teixeira, W.G.; Lehmann, J.; Nehls, T.; de Macedo, J.L.V.; Blum, W.E.H.; Zech, W. Long term effects of manure, charcoal and mineral fertilization on crop production and fertility on a highly weathered Central Amazonian upland soil. Plant Soil 2007, 291, 275-290. [CrossRef]

(C) 2020 by the authors. Licensee MDPI, Basel, Switzerland. This article is an open access article distributed under the terms and conditions of the Creative Commons Attribution (CC BY) license (http://creativecommons.org/licenses/by/4.0/). 